\title{
Tumor suppressor RKIP inhibits prostate cancer cell metastasis and sensitizes prostate cancer cells to docetaxel treatment
}

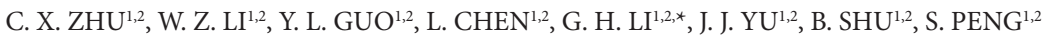 \\ ${ }^{1}$ The Central Hospital of Wuhan, Tongji Medeical College, Huazhong University of Science and Technology, Wuhan, China; ${ }^{2}$ Key Laboratory for \\ Molecular Diagnosis of Hubei Province, China \\ *Correspondence: guohao1125m@sina.com
}

Received February 3, 2017 / Accepted July 12, 2017

\begin{abstract}
Raf kinase inhibitory protein (RKIP) is a well-established metastasis suppressor that is frequently down-regulated in aggressive cancers. However, the impact of RKIP on cancer cell invasion and metastasis in prostate cancer is still elusive. To this end, we overexpressed RKIP in two prostate cancer cell lines. We found that overexpression of RKIP inhibited prostate cancer cells proliferation, migration and invasion. Mechanistically, we found that RKIP overexpression led to down-regulation of the NF-kB signaling pathway and inhibition of the epithelial-to-mesenchymal transition, which is important step for cancer metastasis. In addition, overexpression of RKIP can promote drug effects of docetaxel on prostate cancer cell lines. In conclusion, overexpression of RKIP significantly inhibits prostate cancer cell migration and metastasis, and overexpression of RKIP could aid prostate cancer treatment and therapy.
\end{abstract}

Key words: RKIP, prostate cancer, docetaxel treatment, inhibition

Raf kinase inhibitory protein-RKIP (also known as PEBP1) is a member of the evolutionarily conserved phosphatidylethanolamine-binding protein family. This protein family is ubiquitously expressed within a panoply of organisms, including humans, yeast, bacteria, and plants. RKIP regulates a variety of physiological processes such as differentiation, cell cycle, apoptosis, and contractile activity of cardiomyocytes. RKIP has been implicated as a suppressor of metastatic progression in an orthotopic murine model using androgen-independent prostate tumor cells [1]. The RKIP is a conserved cytosolic protein with wide tissue expression and does not share significant homology with other kinase inhibitors. Although primary prostate tumor growth was unaffected, RKIP inhibited both vascular invasion and lung metastases. RKIP is depleted or deficient in a number of tumors, including prostate, breast, melanoma, hepatocellular carcinoma, and colorectal cancer [1-6]. Taken together, these results suggest that RKIP may function as a general metastasis suppressor.

RKIP modulates at least three critical intracellular signaling pathways in mammalian cells, including the signaling cascades of Raf/MEK/ERK, NFkB, glycogen synthase kinase-3 $\beta$, and $G$ protein-coupled receptors (GPCRs) [7, 8]. RKIP inhibits MAPK signaling partially by directly binding to Raf-1, thereby preventing the phosphorylation of Raf-1 and the activation of MEK and downstream components of the signaling cascade $[9,10]$. Conversely, phosphorylation of RKIP at S153 by Protein Kinase C dissociates RKIP from Raf, enabling MEK and MAPK activation. Phosphorylated RKIP can inhibit the downregulation of G protein-coupled receptors (GPCRs), thereby mediating the crosstalk between MAPK and GPCR signaling pathways $[8,11]$. RKIP can also suppress NFKB activation in response to tumor necrosis factor alpha (TNF-alpha) or interleukin 1 beta [12], potentiating the efficacy of chemotherapeutic agents and sensitizing prostate and breast cancer cells to drug-induced apoptosis [13].

Loss or silencing of metastasis suppressor genes plays key roles in cellular growth, epithelial-to-mesenchymal transition (EMT), invasion and metastasis. It has been reported that restoration of RKIP reduced spontaneous lung metastasis. Significant down-regulation of RKIP has been found in melanoma cell lines compared to normal melanocytes [14]. Stable transfection of melanoma cells with RKIP showed significant inhibition of invasiveness in vitro. Mechanistically, RKIP ensures chromosomal integrity by preventing MAPK inhibition of Aurora B kinase and the spindle checkpoint [15]. Although genomic instability resulting from RKIP loss could contribute to metastatic progression, this mechanism 
is unlikely to give rise to a common phenotype in multiple tumor types. In addition, RKIP silencing has been shown to destabilize GSK $3 \beta$ and activate its downstream targets, which culminates in the expression of $\beta$-catenin, SNAIL and SLUG. $\beta$-catenin, SNAIL and SLUG are known to promote EMT, cellular invasion and metastasis.

In the present study, we report that overexpression of RKIP inhibits prostate cancer cell proliferation, migration, invasion and metastasis. Mechanistically, we found that RKIP overexpression led to downregulation of the ERK signaling pathway and inhibition of the EMT. In addition, overexpression of RKIP can promote the drug effect of docetaxel on prostate cancer cell lines. Moreover, the expression of RKIP is significantly associated with prostate cancer prognosis and overall survival [16]. And in metastases of prostate cancer patients, the expression of RKIP is lower than that of normal prostate or the primary prostate tumor [17]. In conclusion, overexpression of RKIP significantly inhibits prostate cancer cell migration and metastasis, and rescuing of RKIP could help prostate cancer treatment and therapy.

\section{Materials and methods}

Cell lines and cell culture. PC3 and P69 cell lines were obtained from American Type Culture Collection (ATCC, Rockville, MD, USA) and cultured in DMEM medium (Gibco ${ }^{\circ}$ life technology, Carlsbad, CA) supplemented with $4.5 \mathrm{~g} / \mathrm{l}$ glucose, L-glutamine, sodium pyruvate and 10\% FBS.

Antibodies and reagents. Docetaxel was purchased from Sigma (St. Louis, MO, USA); Anti-Snail (Catalogue number ab53519), anti-E-cadherin (ab76055), anti-COX-2 (ab52237), anti-Vimentin (ab8978), anti-GAPDH (ab8245) antibodies were from Abcam; anti-STAT3 (9145), anti-pSTAT3 (12640), anti-Erk1/2 (4695), anti-p-Erk1/2 (4370), anti-NFkB p65 (8242), anti-H3 (4499) antibodies were from Cell signaling technology company.

Generation of RKIP overexpression cells. RKIP was cloned into the expression vector pcDNA3.1 vector (Invitrogen). PC3 and PC69 cells were transfected with pcDNA3.1RKIP or vector by using lipofectamine 2000 (Invitrogen, Carlsbad, CA). Stable overexpression cell lines were generated for further cell function analysis.

Cell proliferation. Cells were plated at $1 \times 10^{4}$ cells/well in triplicate in 96-well microplates for both, control and docetaxel treatment $(0.5 \mu \mathrm{g} / \mathrm{ml})$. At each time points $(0,24$ and $48 \mathrm{hrs}$ ), $10 \mu \mathrm{l} \mathrm{CCK8}$ solution (Boster Bio-engineering, Wuhan, China) was added to each well and incubated for $1 \mathrm{~h}$. Optical density values (OD) at wavelength $450 \mathrm{~nm}$ were measured by Multiscan spectrum microplate reader (Thermo, Waltham, MA, USA).

Cell migration assay. For transwell migration assay, indicated cells $\left(1 \times 10^{5}\right.$ cells/chamber $)$ in $100 \mu \mathrm{l}$ serum-free DMEM culture medium were seeded into the upper well of the transwell chamber (Costar). An aliquot of $600 \mu \mathrm{l}$ of culture medium supplemented with 10\% FBS was added into the lower well of the chamber. After $24 \mathrm{~h}$, cells in the upper well were removed with a cotton swab. Cells that migrated into the lower well were washed with phosphate-buffered saline (PBS), fixed in 3.7\% paraformaldehyde at room temperature and stained by $0.2 \%$ crystal violet in $2 \%$ ethanol. Cells were photographed and counted under microscope. The number of migrated cells was expressed as mean value \pm standard deviation (s.d.).

Transwell invasion assay. Transwells were first coated with Matrigel (1:3 dilution) in serum-free media for $2 \mathrm{~h}$ at $37^{\circ} \mathrm{C}$. The rest of the assay was performed as described above (see migration assay).

Western blot analysis. Total cell lysates were collected with immunoprecipitation (IP) lysis Buffer $(20 \mathrm{mM}$ Tris [pH 7.5], $150 \mathrm{mM} \mathrm{NaCl}, 1$ mM EDTA, 1 mM EGTA, 1\% Triton $\mathrm{X}-100,2.5 \mathrm{mM}$ sodium pyrophosphate, $1 \mathrm{mM}$ beta-glycerolphosphate, $1 \mathrm{mM}$ sodium orthovanadate, $1 \mathrm{mM}$ PMSF and protease inhibitor cocktail). Whole cell lysates were obtained by sonication followed by centrifugation. Protein concentration was measured by BCA protein assay kit (Pierce). Equal amounts of cell lysates were subjected to electrophoresis using SDS-PAGE and transferred to polyvinyldifluoride membrane (Bio-Rad). Membranes were blocked with 5\% milk (in PBS-T) for $30 \mathrm{~min}$, followed by primary antibody incubation overnight at $4{ }^{\circ} \mathrm{C}$, after three washes with PBS-T ( 5 min each), incubated with secondary antibody ( $5 \%$ milk in PBS-T ) for 60 min, signal was detected by ECL (Amersham) following the manufacturer's instructions.

Statistical analysis. All data were presented as the mean \pm standard deviation (SD). Data were analyzed using student's t-test and $\mathrm{p}<0.05$ was considered statistically significant.

\section{Results}

Establishment of RKIP stable cell lines. To study the functions of RKIP in prostate cancer cells, construct of RKIP was generated and stably transfected into PC 3 cells. As shown in Figure 1, RKIP expression was significantly increased in RKIP-transfected cells, whereas RKIP expression remained unaffected in vector-transfected cells.

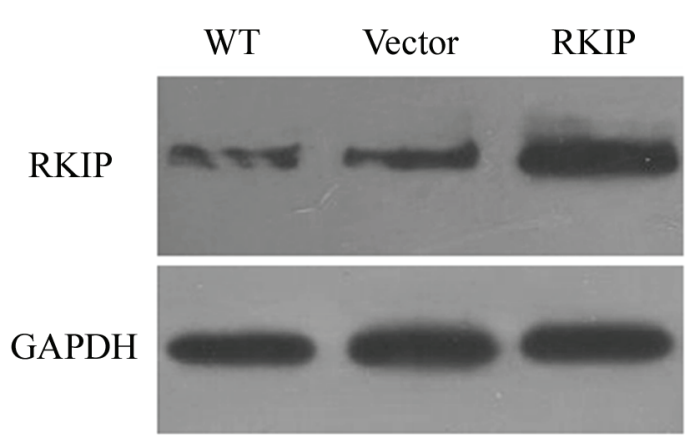

Figure 1. Establishment of RKIP stable cell lines. Western blot analysis showed ectopic expression of RKIP in PC3 cells. GAPDH was used as a loading control. 


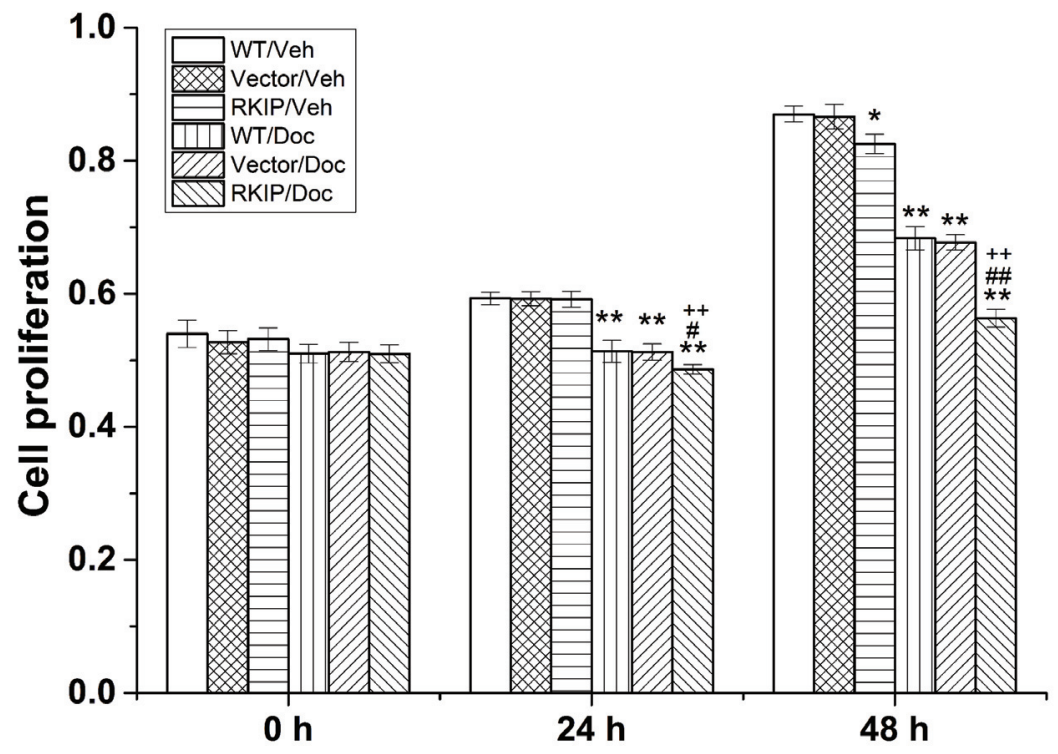

Figure 2. RKIP overexpression inhibited cell proliferation. Indicated cells were treated with vehicle (Veh) or docetaxel (Doc, $0.5 \mathrm{~g} / \mathrm{ml}$ ) for $0 \mathrm{~h}, 24 \mathrm{~h}$ and $48 \mathrm{~h}$. Cell growth was detected using the CCK-8 assay. Mean $\pm \mathrm{SD}, \mathrm{n}=3 ;{ }^{*} \mathrm{p}<0.05,{ }^{* *} \mathrm{p}<0.01$ V.S. Veh; $+\mathrm{p}<0.05,++\mathrm{p}<0.01$ V.S. Doc; \#p<0.05, \#\#p<0.01 V.S. RKIP+Veh.
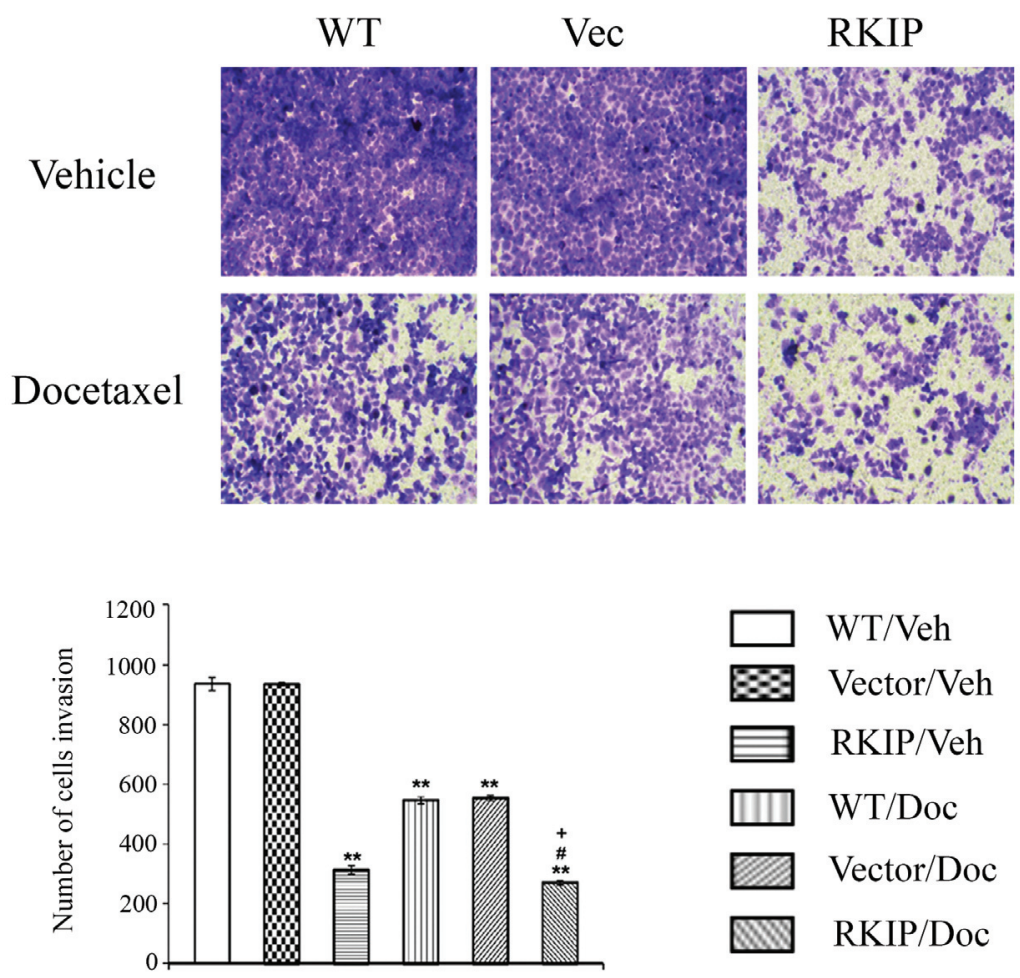

Figure 3. Cell migration was impaired by RKIP overexpression. Migration assay of indicated cells treated with vehicle $(\mathrm{Veh})$ or docetaxel $(0.5 \mathrm{~g} / \mathrm{ml})$ for $24 \mathrm{~h}$ was performed in transwell chambers. Cells that migrated from the upper well of a transwell chamber into the lower well were stained, photographed and counted. Data are presented as the mean value from three different fields \pm SD; ${ }^{* *}$ p $<0.01$ V.S. Veh; + p $<0.01$ V.S. Doc; $\# p<0.01$ V.S. RKIP+Veh.
RKIP inhibits cancer cell proliferation. Docetaxel has been applied to treat prostate cancer. To examine the effects of RKIP overexpression and docetaxel treatment on the proliferation of prostate cancer cells, we monitored cell proliferation using CCK- 8 assay. As shown in Figure 2, docetaxel $(0.5 \mathrm{~g} / \mathrm{ml})$ or RKIP overexpression can inhibit PC3 cells proliferation. In addition, RKIP overexpression significantly potentiated the inhibition effects of docetaxel on PC3 cell proliferation (Figure 2). These data indicate a role of RKIP in cell proliferation of PC3 cells.

RKIP inhibits prostate cancer cell migration. To determine the function of RKIP in prostate cancer metastasis, transwell assays were carried out to quantitatively determine the effect of RKIP on cell migration. As shown in Figure 3, similar numbers of wild-type (WT) and vectortransfected cells migrated to the lower face of the transwell membrane, whereas the RKIP overexpression cells and docetaxel treated cells exhibited a strongly inhibited motility, with only $33 \%$ and $58 \%$ cells migrating. In addition, RKIP overexpression significantly potentiated the inhibition effects of docetaxel on PC3 cell migration. Our data suggest that RKIP may play a role in inhibiting cancer cell migration (Figure 3).

RKIP inhibits prostate cancer cell invasion. It has been reported that RKIP is associated with cancer metastasis. However, the function of RKIP in prostate cancer cell has never been explored. Then, we investigated whether RKIP overexpression affects the invasive ability of PC3 cells by in vitro invasion assay. RKIP overexpression cells and docetaxel treated cells showed dramatically reduced invasive ability (Figure 4). In addition, the overexpression of RKIP can strengthen the docetaxel effects on PC3 cell invasion.

Related proteins were regulated by RKIP overexpression. To explore the possible mechanism by which RKIP inhibits cancer cell invasion, expression levels of several related proteins, including NF-kB, Snail, E-cadherin, COX2, vimentin, STAT3, and ERK1/2 were detected by Western blot. Total expression level and phosphorylated ERK does not change after RKIP overexpression (Figure 5). Interestingly, Snail, 
COX-2, Vimentin and p-STAT3 level were repressed by RKIP overexpression (Figure 5). E-cadherin was upregulated by RKIP overexpression. Furthermore, we found that RKIP overexpression or docetaxel treatment inhibited the translocation of $\mathrm{NF \kappa B}$ to the nucleus (Figure 6). Interestingly, RKIP overexpression can significantly potentiate the inhibition effects of docetaxel on the translocation of NFKB.

\section{Discussion}

Prostate cancer is the most common non-cutaneous malignancy in the world. Since secondary hormone therapy of castration-resistant prostate cancer lacks effectiveness, a chemotherapeutic agent docetaxel is the standard treatment [18]. However, docetaxel resistance emerges invariably and fast which leads to the relapse of prostate cancer, not to mention the length of the treatment and systemic side effects [19]. Docetaxel resistance is either de novo or acquired through various mechanisms including genetic alterations, decreased influx and increased efflux of the drugs [20]. To improve
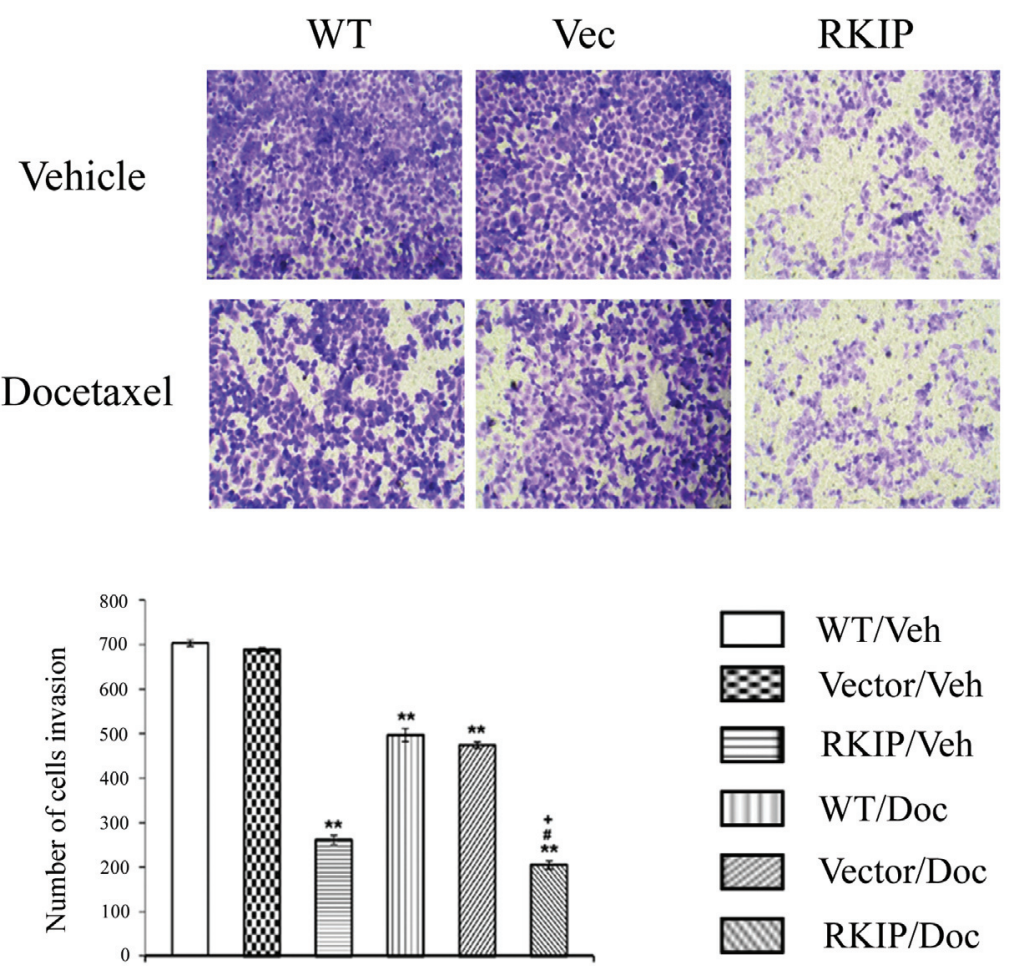

Figure 4. Cell invasion was impaired by RKIP overexpression. Invasion assay of indicated cells treated with vehicle $(V e h)$ or docetaxel $(0.5 \mathrm{~g} / \mathrm{ml})$ for $24 \mathrm{~h}$ was performed in extracellular matrix (ECM)-coated transwell chambers. Data are presented as the mean value from three independent experiments $\pm S D ;{ }^{*} p<0.05,{ }^{* *} p<0.01$ V.S. Veh.
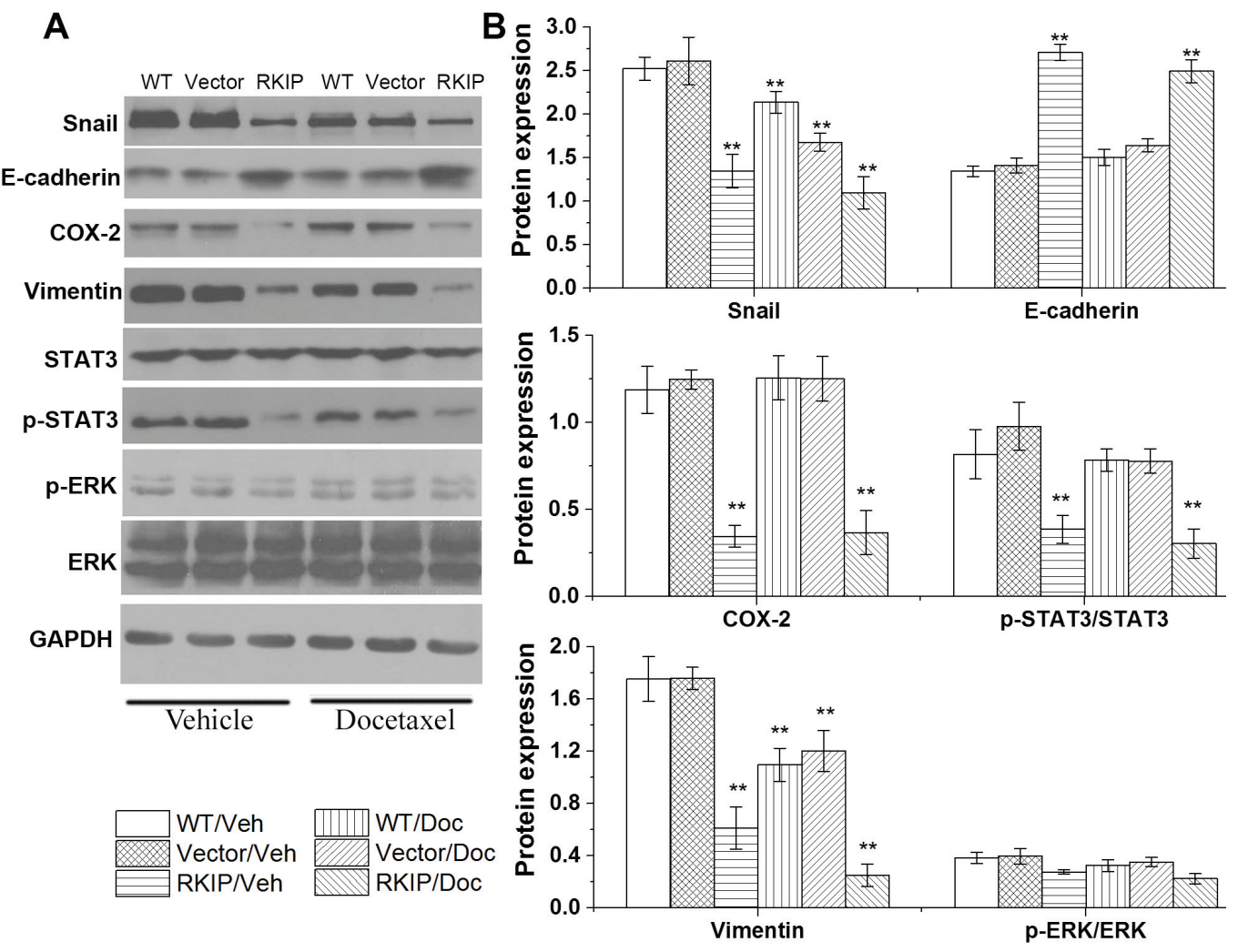

Figure 5. Immunoblotting of signaling components in indicated cells treated with vehicle (Veh) or docetaxel $(0.5 \mathrm{~g} / \mathrm{ml})$ for $24 \mathrm{~h}$. GAPDH was used as a loading control (A). Quantification of western blot signals was shown in (B). The y axis represents the relative protein levels in indicated cells. The relative levels of Snail, COX2, E-cadherin and Vimentin were normalized to GAPDH level. The activity of ERK and STAT3 was normalized to the corresponding total protein level. Data are presented as the mean value from three independent experiments $\pm \mathrm{SD}$; * $\mathbf{p}<0.05,{ }^{* *} \mathbf{p}<0.01$ V.S. Veh. 


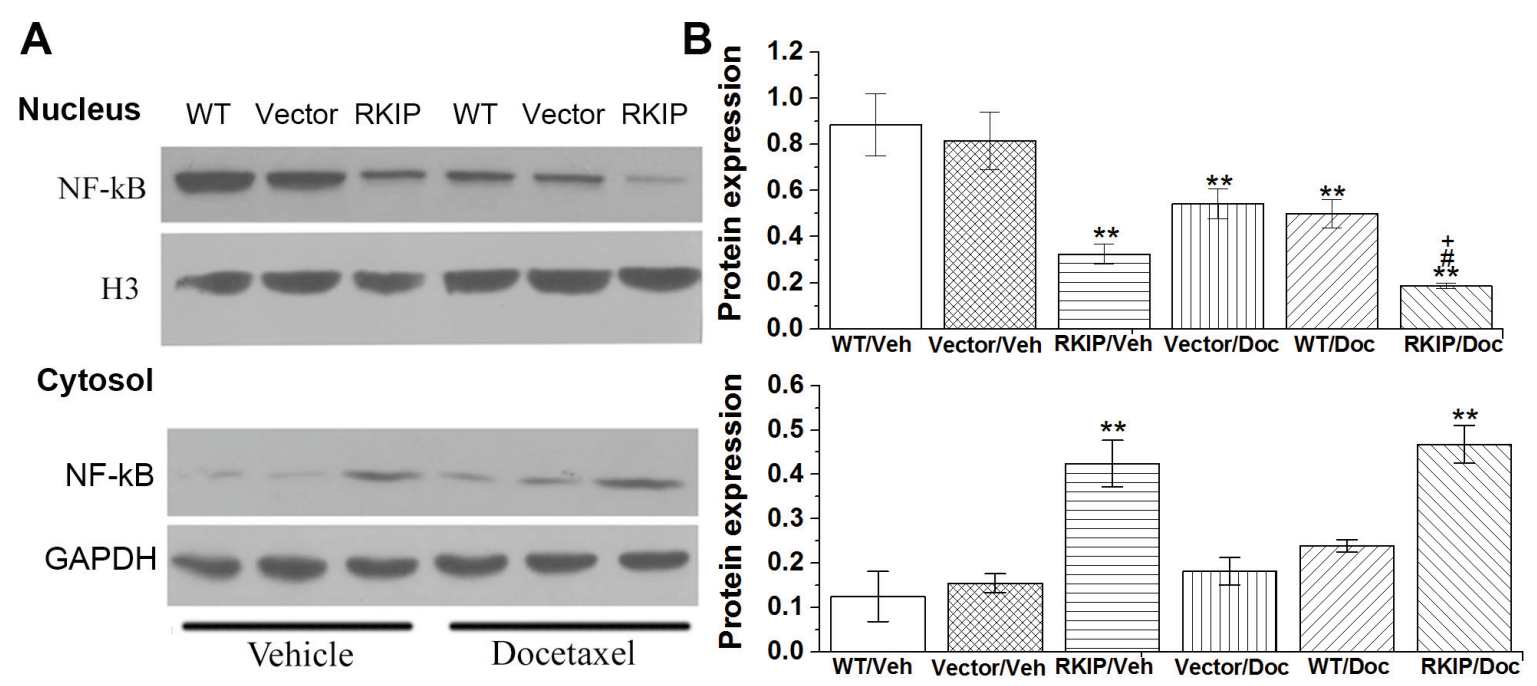

Figure 6. Cell fraction assay of indicated cells treated with vehicle (Veh) or docetaxel ( $0.5 \mathrm{~g} / \mathrm{ml})$ for $24 \mathrm{~h}$. RKIP overexpression or docetaxel treatment inhibited the translocation of NFkB to the nucleus (A). Quantification of western blot signals are shown in (B). The relative level of nucleus NF-kB was normalized to $\mathrm{H} 3$ level. The relative level of cytosol NFKB was normalized to GAPDH level. Data are presented as the mean value from three independent experiments $\pm \mathrm{SD} ;{ }^{\star} \mathrm{p}<0.05,{ }^{* *} \mathrm{p}<0.01$ V.S. Veh; $+\mathrm{p}<0.01$ V.S. Doc; $\# \mathrm{p}<0.01$ V.S. RKIP+Veh.

outcomes, docetaxel in combination with other agents has been evaluated. For example, several combination therapies and small P-glycoprotein inhibitors have been proposed to improve the therapeutic potential of docetaxel in prostate cancer. In addition, novel therapeutic strategies that may allow reversal of docetaxel resistance include alterations of enzymes, improving the drug uptake and enhancement of apoptosis $[19,20]$. Here we found that overexpression of RKIP can promote the drug effect of docetaxel on inhibiting the prostate cancer cell lines proliferation. Consistent with previous report, RKIP expression levels in tumorigenic human prostate and breast cancer cells are rapidly induced upon chemotherapeutic drug treatment to sensitize the cells to apoptosis. In addition, RKIP expression highly correlates with the onset of apoptosis, and ectopic expression of RKIP re-sensitizes DNA-damaging agent-resistant cells to undergo apoptosis. Down-regulation of endogenous RKIP by expression of antisense and small interfering RNA (siRNA) confers resistance on sensitive cancer cells to anticancer drug-induced apoptosis [13]. Thus, activation of RKIP would overcome the docetaxel resistance in prostate cancer and promote the efficacy of chemotherapy in the treatment of prostate cancer. Moreover, a combinatory treatment with antagonists to RKIP's downstream signaling components and docetaxel will be a better strategy in the prostate cancer therapy.

Down-regulation of RKIP was observed in metastatic prostate cancer cell lines as compared to non-metastatic cell lines. Additionally, immunohistochemical staining showed moderate to high RKIP expression in normal prostate and primary prostate tumors, whereas low or undetectable levels were observed in metastatic foci. These data suggest that RKIP may function as a metastasis suppressor in prostate cancer development. Here, we found that overexpression of RKIP inhibits prostate cancer cell migration and invasion. Snail is regarded as a key inducer of EMT and plays an important role in cancer metastasis [21]. Our data indicate that RKIP overexpression may downregulate the expression of Snail, thus inhibiting the EMT (Figure 6). More importantly, we found that RKIP overexpression inhibited the translocation of NFKB from cytoplasm into nucleus, which further affected downstream gene expression, including E-cadherin, COX2 and vimentin.

Acknowledgements: This work is supported by the Project of Health and Family Planning Commission of Hubei Province (NO. WJ2017M184).

\section{References}

[1] FU Z, SMITH P C, ZHANG L, RUBIN MA, DUNN RL et al. Effects of raf kinase inhibitor protein expression on suppression of prostate cancer metastasis. J Natl Cancer Inst 2003; 95: 878-889.

[2] AKAISHI J, ONDA M, ASAKA S, OKAMOTO J, MIYAMOTO $S$ et al. Growth-suppressive function of phosphatidylethanolamine-binding protein in anaplastic thyroid cancer. Anticancer Res 2006; 26: 4437-4442.

[3] AL-MULLA F, HAGAN S, BEHBEHANI AI, BITAR MS, GEORGE SS et al. Raf kinase inhibitor protein expression in a survival analysis of colorectal cancer patients. J Clin Oncol 2006 24: 5672-5679. doi: 10.1200/JCO.2006.07.5499

[4] FU Z, KITAGAWA Y, SHEN R, SHAH R, MEHRA R et al. Metastasis suppressor gene Raf kinase inhibitor protein (RKIP) is a novel prognostic marker in prostate cancer. Prostate 2006; 66: 248-256. doi: 10.1002/pros.20319 
[5] HAGAN S, AL-MULLA F, MALLON E, OIEN K, FERRIER $\mathrm{R}$ et al. Reduction of Raf-1 kinase inhibitor protein expression correlates with breast cancer metastasis. Clin Cancer Res 2005; 11: 7392-7397. doi: 10.1158/1078-0432.CCR-05-0283

[6] SCHUIERER MM, BATAILLE F, HAGAN S, KOLCH W, BOSSERHOFF AK. Reduction in Raf kinase inhibitor protein expression is associated with increased Ras-extracellular signal-regulated kinase signaling in melanoma cell lines. Cancer Res 2004; 64: 5186-5192. doi: 10.1158/0008-5472. CAN-03-3861

[7] KELLER ET, FU Z, BRENNAN M. The biology of a prostate cancer metastasis suppressor protein: Rafkinase inhibitor protein. JCell Biochem 2005; 94: 273-278. doi: 10.1002/jcb.20169

[8] TRAKUL N, ROSNER MR. Modulation of the MAP kinase signaling cascade by Raf kinase inhibitory protein. Cell Res 2005; 15: 19-23. doi: 10.1038/sj.cr.7290258

[9] TRAKUL N, MENARD RE, SCHADE GR, QIAN Z, ROSNER MR. Raf kinase inhibitory protein regulates Raf-1 but not B-Raf kinase activation. J Biol Chem 2005; 280: 2493124940. doi: 10.1074/jbc.M413929200

[10] YEUNG K, SEITZ T, LI S, JANOSCH P, MCFERRAN B et al. Suppression of Raf-1 kinase activity and MAP kinase signalling by RKIP. Nature 1999; 401: 173-177. doi: 10.1038/43686

[11] LORENZ K, LOHSE MJ, QUITTERER U. Protein kinase C switches the Raf kinase inhibitor from Raf-1 to GRK-2. Nature 2003; 426: 574-579. doi: 10.1038/nature02158

[12] YEUNG K C, ROSE D W, DHILLON A S, YAROS D, GUSTAFSSON $M$ et al. Raf kinase inhibitor protein interacts with NF-kappaB-inducing kinase and TAK1 and inhibits NFkappaB activation. Mol Cell Biol 2001; 21: 7207-7217. doi: 10.1128/MCB.21.21.7207-7217.2001

[13] CHATTERJEE D, BAI Y, WANG Z, BEACH S, MOTT S et al. RKIP sensitizes prostate and breast cancer cells to druginduced apoptosis. J Biol Chem 2004; 279: 17515-17523. doi: 10.1074/jbc.M313816200
[14] SCHUIERER MM, BATAILLE F, HAGAN S, KOLCH W, BOSSERHOFF AK. Reduction in Raf kinase inhibitor protein expression is associated with increased Ras-extracellular signal-regulated kinase signaling in melanoma cell lines. Cancer Res 2004; 64: 5186-5192. doi: 10.1158/0008-5472. CAN-03-3861

[15] EVES EM, SHAPIRO P, NAIK K, KLEIN UR, TRAKUL N et al. Raf kinase inhibitory protein regulates aurora $\mathrm{B}$ kinase and the spindle checkpoint. Mol Cell 2006; 23: 561-574. doi: 10.1016/j.molcel.2006.07.015

[16] FU Z, KITAGAWA Y, SHEN R, SHAH R, MEHRA R et al. Metastasis suppressor gene Raf kinase inhibitor protein (RKIP) is a novel prognostic marker in prostate cancer. Prostate 2006; 66: 248-256. doi: 10.1002/pros.20319

[17] KELLER ET, FU Z, YEUNG K, BRENNAN M. Raf kinase inhibitor protein: a prostate cancer metastasis suppressor gene. Cancer Lett 2004, 207: 131-137.

[18] GALSKY MD, VOGELZANG NJ. Docetaxel-based combination therapy for castration-resistant prostate cancer. Ann Oncol 2010; 21: 2135-2144. doi: 10.1093/annonc/mdq050

[19] COLLOCA G, VENTURINO A, CHECCAGLINI F. Secondline chemotherapy in metastatic docetaxel-resistant prostate cancer: a review. Med Oncol 2012; 29: 776-785. doi: 10.1007/ s12032-011-9855-6

[20] GANJU A, YALLAPU MM, KHAN S, BEHRMAN SW, CHAUHAN SC et al. Nanoways to overcome docetaxel resistance in prostate cancer. Drug Resist Updat 2014; 17: 13-23. doi: 10.1016/j.drup.2014.04.001

[21] KUDO-SAITO C, SHIRAKO H, TAKEUCHI T, KAWAKAMI Y. Cancer metastasis is accelerated through immunosuppression during Snail-induced EMT of cancer cells. Cancer Cell 2009; 15: 195-206. doi: 10.1016/j.ccr.2009.01.023 